\title{
POST-VACCINATION GIANT CELL HEPATITIS WITH AUTOIMMUNE HEMOLYTIC ANEMIA
}

\author{
Mai Abd El Salam ${ }^{1}$ Ahmad El-Hennawy², and Hanaa El-Karaksy² \\ ${ }^{1}$ Cairo University Childrens Hospital \\ ${ }^{2}$ Cairo University Kasr Alainy Faculty of Medicine
}

October 19, 2020

\begin{abstract}
Giant cell hepatitis (GCH) with autoimmune hemolytic anemia (AIHA) is a rare entity in children. GCH is commonly described in infants. Vaccination has been incriminated as a trigger of development of AIHA in infants and children. However, vaccination has not been reported, till the time of writing the manuscript, to trigger the combination of Giant cell hepatitis with autoimmune hemolytic anemia. GCH with AIHA is usually fatal. Immunosuppressive treatment with conventional drugs offers some temporary response. We, herein, report a case of GCH with AIHA in a 4-month old male infant, following receipt of oral polio vaccine (OPV) and intramuscular diphtheria-tetanus-pertussis (DPT) vaccine. The patient was resistant to standard immunosuppressive combinations, and rescue therapy with Rituximab was used.
\end{abstract}

\section{Hosted file}

Main text.pdf available at https://authorea.com/users/368483/articles/487591-postvaccination-giant-cell-hepatitis-with-autoimmune-hemolytic-anemia

\section{Hosted file}

Figure 1.pdf available at https://authorea.com/users/368483/articles/487591-post-vaccinationgiant-cell-hepatitis-with-autoimmune-hemolytic-anemia

\section{Hosted file}

Figure 2.pdf available at https://authorea.com/users/368483/articles/487591-post-vaccinationgiant-cell-hepatitis-with-autoimmune-hemolytic-anemia 